\title{
A GEOGRAFIA DA DIFERENÇA NAS VEREDAS DE GUIMARÃES ROSA
}

\section{THE GEOGRAPHY OF DIFFERENCE IN THE PATHS OF GUIMARÃES ROSA}

\author{
Paulo Petronilio CORREIA*
}

\begin{abstract}
RESUMO: O objetivo desse artigo é mapear a geografia da Diferença que povoa a literatura do senhor João Guimarães Rosa, bem como cartografar o estatuto do Narrador, seus múltiplos signos e aprendizados em suas travessias. Guimarães Rosa, em sua obra Grande Sertão: veredas, embaralhou os códigos da sua própria língua e do pensamento fazendo assim emergir um sertão cheio de "ocultos caminhos", dobrando o pensamento para fora e para dentro, nos convidando a construir uma terceira margem através do "demônio" da criação. Assim, esse artigo propõe evidenciar nas veredas de Rosa uma narrativa da diferença onde as vozes dos signos emitidos por Riobaldo Tatarana, personagem-mor, nos fazem compreender que pensar é decifrar as pressões secretas da obra de arte, dobrando o pensamento ao infinito. Tal literatura se evidencia como forte presença de signos que se desdobram formando uma complexa máquina da diferença.
\end{abstract}

Palavras-chave: Signo. Diferença. Aprendizagem. Narrador. Geografia

ABSTRACT: The aim of this paper is to map the geography of difference that inhabits the literature of Mr. João Guimarães Rosa, as well as mapping the status of the Narrator, his multiple signs and learnings on their journeys . Guimarães Rosa, in his Grande Sertão : paths, scrambled codes of their own language and thought emerge thus making a wild full of " hidden paths ", doubling thought out and in, inviting us to build a third bank through the " demon " of creation. Thus, this paper proposes the paths show Rose a narrative of difference where the voices of the signs emitted by Riobaldo Tatarana character - mor, we do understand that thinking is to decipher the secret pressures of the artwork, doubling thought to infinity . Such literature is evident as a strong presence of signs that unfold to form a complex machine difference.

Keywords: Zodiac. Difference. Learning. Narrator. Geography

\section{Introdução}

O movimento infinito é duplo, e não há senão uma dobra de um a outro. É neste sentido que se diz que pensar e ser são uma só e mesma coisa. (Deleuze; Guattari, 1992, p. 48)

Este trabalho tem como objetivo central mostrar que a literatura de Guimarães Rosa, o Grande sertão: veredas, que surgiu dez anos depois de sua estréia com Sagarana, em 1956, é um exemplo vivo de uma escritura da Diferença, pois o sertão de

\footnotetext{
* Doutor em Filosofia da Educação pela Universidade Federal do Rio Grande do Sul (UFRGS), professor Adjunto II de Filosofia da Educação da Universidade de Brasília/FUP (UnB/FUP). E-mail: ppetronilio@uol.com.br.
} 
Rosa se revela enquanto subjetividade onde os signos que nos forçam-nos- pensar, nos mostram que a arte literária é uma prodigiosa máquina que revela signos e aprendizagens estendendo-os ao infinito. Tal subjetividade impregnada nas veredas de Rosa é o retrato complexo de uma nova história e uma nova geografia do pensamento. Essa geografia situa-se no campo esquizo e nômade em que um novo plano de subjetivação instaura a partir de uma nova escritura que beira a margem da Diferença. Para tal travessia, teremos como ponto de partida a experimentação de conceitos que fazem parte do coração da Diferença como Signos, devires, aprendizagens e outras dobras que são co-tecidas em sua máquina literária. Entende-se aqui por Filosofia ou Geografia da Diferença o pensamento pós-nietzschiano de Deleuze e Guattari em que instaura uma nova forma de pensar no coração da formação, da criação e da fabricação de conceitos, pois a gênese da Diferença se ancora no ato de criação e recriação da própria vida. Depois de Nietzsche emerge uma nova imagem e uma nova geografia da diferença: um pensamento sem imagem.

Assim, percorrer a literatura do senhor João Guimarães Rosa, significa fazer um giro no coração da Filosofia da Diferença e experimentarmos alguns fluxos, devires e intensidades em suas veredas que se contornam e se desenham como infinitos signos a decifrar, a interpretar. São estes signos a força viva e ativa do pensamento. A vereda como signo da Diferença se traduz como caminho e descaminho do pensar. É este signo que provoca o efeito violento no pensamento arrombando-o e criando novas formas de pensar os múltiplos aprendizados, o surpreendente pluralismo nas travessias de Riobaldo. São estes aprendizados a gênese do ato de pensar no pensamento.

O sertão, com isso, forma uma complexa geografia do pensamento sem começo e sem fim, passando a existir o "meio", um campo híbrido, plural, polifônico e rizomático. É essa nova geografia a rebeldia da diferença pois Rosa, como rebelde de sua língua, fez uma nova linguagem nascer e se estender ao infinito. É essa travessia que o narrador Riobaldo como um homem que gosta de contar, emendar e desemendar ideias que nos arrasta: travessia para o caos e para o infinito. É essa travessia que nos faz remexer vivos e ao mesmo tempo nos faz acelerar o pensamento. Essa é a travessia do personagem Riobaldo, a minha travessia que é, de certa maneira, a nossa travessia no imenso sertão-mundo. Percorremo-la e façamo-la, enveredando e desenveredando a escritura enquanto vereda do pensamento e signo da Diferença.

\section{A vereda é o signo da diferença}


Para percorrer essa travessia nebulosa de Guimarães Rosa, esse mestre do amálgama, atenho-me ao pensamento da Diferença de Gilles Deleuze em Proust e os Signos (2003), pois encontrei nesse pensador um suporte teórico que me faz percorrer as veredas de Rosa em busca de um sertão cuja expressão é a pura Diferença, pois é Riobaldo, personagem sósia de Guimarães que nos excita a pensar uma terceira margem que certamente deve ser criada pelo "demônio" da criação, da imaginação e da invenção de novas possibilidades de vida. É a complexa travessia de Riobaldo-narrador que marca todo esse "chão de encruzilhadas" que nos força a pensar ao nos colocar diante de signos nebulosos, aporéticos e enigmáticos que é o próprio sertão. Desde o começa Riobaldo nos convida a sermos especuladores de ideias, pois esse é, certamente, a máxima do sertão roseano: "E me inventei neste gosto de especular ideia. (ROSA, 1978, p. 11). Desse modo, Riobaldo, como um especulador de ideias, nos convida a especular, a perscrutar esse sertão fazendo uso do pensamento. É essa ideia plantada por Guimarães Rosa que deve ser colocada em questão, pois o sertão, enquanto edifício filosófico-literário nos coloca a todo momento "Nonada" e nos joga na "rua no meio do redemoinho".

Parto do ponto de vista deleuzeano de que "É preciso sentir o efeito violento de um signo, e que o pensamento seja como que forçado a procurar o sentido do signo". (DELEUZE, 2003, p.22). Desse modo, a aprendizagem do sertão se dá nessa travessia constante que fazemos diante do pensamento, pois é esse "efeito violento" que o sertão provoca e que nos força a buscar o sentido da vida através da arte da decifração e da interpretação dos signos. Assim, em Deleuze, a aprendizagem se dá no encontro com o signo, com algo que rouba a nossa paz e nos coloca diante do pensamento. É Rio baldo que nos coloca para "remexer vivos" diante da busca dos signos do sertão que é construído na linguagem embaralhada e confusa. O mundo de Riobaldo que é, de certa forma, o nosso mundo, "vacila na corrente do aprendizado" (DELEUZE, 2003, p.25). É esse aprendizado diante dos signos do pensamento no próprio pensamento que Riobaldo em toda a sua travessia nos convida, pois para ele, pensar é estender o pensamento ao infinito. É dar velocidades infinitas ao pensamento. É o sertão enquanto Dobras barrocas que nos faz olhar para dentro e para fora de nós mesmos e do próprio sertãomundo.

O poeta é Guimarães Rosa. Ele é, sem dúvida, um exemplo vivo que temos de um escritor filósofo. Isso não é simplesmente pelo fato de sua maquinaria literária nos forçar a pensar. Mais que isso, ela arrasta-nos para fora dos sulcos costumeiros da 
linguagem e violenta o nosso pensamento, fazendo dobras dentro e fora do pensamento em um jogo interminável. Diante de sua criação, somos movimentados pelos efeitos de massa que movimentam cada palavra, nos lançando assim no redemoinho e nutrindo várias turbulências saindo dos turbilhões das palavras e desaguando no caos. Guimarães Rosa faz emergir uma escritura nômade, embaralhada e enigmática como as Dobras do pensamento. Rosa é consciente de que o mundo é constantemente agitado, embaralhado, desordenado, pois o caos instala em sua poética.

Ouviremos as sábias palavras do professor Riobaldo Tatarana que nos ensina que "esta vida é de cabeça para baixo" (ROSA, 1978,p.112). O sertão é, de certa forma,a aprendizagem do avesso. O professor é Riobaldo e, dentro desse sertão ele se apresenta:

Sou só um sertanejo, nessas altas idéias navego mal. Sou muito pobre
coitado. Inveja minha pura é de uns conforme o senhor, com toda leitura e
suma doutoração. Não é que eu esteja analfabeto. Soletrei, anos e meio,
meante cartilha, memória e palmatória. Tive mestre, Mestre Lucas, no
Curralinho, decorei gramática, as operações, regra -de- três, atégeografiae
estudo pátrio. Em folhas grandes de papel, com capricho, tracei bonitos
mapas. Ah, não é por falar: mas, desde o começo, me achavam sofismado de
ladino. E que eu merecia de ir para cursar latim, em Aula Régia- que também
diziam. Tempo saudoso! Inda hoje, apreceio um bom livro, despaçado. Na
fazenda O Limãozinho, de um meu amigo VitoSoziano, se assina esse
almanaque grosso, de logogrifos e charadas e outras divididas matérias, todo
ano vem. Em tanto, ponho primazia é na leitura proveitosa, vida de santo,
virtudes e exemplos - missionário esperto engambelando os índios, ou São
Francisco de Assis, Santo Antônio, São Geraldo... Eu gosto muito de moral.
Raciocinar, exortar os outros para o bom caminho, aconselhar a justo.
(ROSA, 1978, p. 14)

Desse modo, Riobaldo Tatarana, como um sertanejo e homem do sertão feito a gente, com sua ironia, nos diz navegar mal das ideias, se coloca como pobre coitado, que de nada sabe, mas desconfia de muita coisa. Ironiza os doutores e nos coloca em nosso lugar. Mas mesmo assim, ele é diferente, pois diverge de todo mundo. Mas diante de seu pouco saber, Riobaldo teve Mestre Lucas, decorou gramática, aprendeu regra-detrês, geografia, estudo pátrio e põe primazia em leitura proveitosa, gosta de moral, raciocinar, dar conselhos. Riobaldo é mestre do logos. É professor- filósofo que vai emendando e desemendando o sertão e nos virando do avesso com sua escritura enviesada, onde somos convidados a entrar nesses intensos fluxos da Riobaldança e percorrer esse pensamento nebuloso. Riobaldo é um professor-jagunço que conta as “coisas divagadas" (ROSA, 1978, p. 19). Assim aprendemos diante dos signos do sertão. Signos que nos forçam a entrar nesse redemoinho e pensar, pois esse sertão "é um pedacinho de pensamento" (ROSA, 1978, p. 19). É esse pedacinho que estamos 
tentando construir, especular, dobrar, desdobrar e virar o mundo do avesso. Nessa efervescência dionisíaca, somos convidados a entrar nesse rio e desaguar na terceira margem a fora. $\mathrm{O}$ rio, é o rio da alegria. $\mathrm{O}$ rio da vida. $\mathrm{O}$ novelo que enrola todos os dias. O lance de dados. Sertão. O rio que corre e escorre intensamente. Assim, vemos surgir um pensamento do tamanho do mundo entre fluxos e cortes permanentes. Um pensar demoníaco que nos joga na mata habitada pelo "demônio" da criação. Um pensamento do avesso é tecido pelo demo, pela tragicidade da vida, enfim, pela arte da palavra emendada e desemendada. Pelos signos do sertão. Signos que nos forçam a decifrar cada margem, cada neblina. Somos lançados nas águas caóticas do demo e, nessa dança da criação, unimos arte e vida e vemos a vida se desdobrar infinitamente no leque do mundo cheio de dobras. Estamos diante de um pensar cujo maior grito é o devir, pois "os brejos vão virando rios" (ROSA, 1978, p. 27) e somos impulsionados a virar o pensamento do avesso e nos lançar nesse rio que despenca ladeira a baixo, ladeira a cima e nos lança rumo ao caos, às águas turvas do rio, nos fazendo ressurgir debaixo da terra. Da vida, da dança, do sertão, das raizamas, do rizoma. Da raiz que brota da terra, surge e ressurge "Nonada". Da potência e do delírio da criação. Da tragicidade da vida, do fundo sombrio e cavernoso que é o sertão- mundo. "O senhor aprende?” (ROSA, 1978, p. 136). São estes múltiplos aprendizados que são construídos nas múltiplas travessias de Riobaldo Tatarana.

\section{Os aprendizados das travessias}

São múltiplos os aprendizados que o mestre Guimarães Rosa nos lançou em toda travessia de Riobaldo Tatarana. Tais aprendizados são emitidos em forma de signos nebulosos, tortuosos e complexos. As linguagens míticas e místicas de Rosa fazem dele um escritor conciso, uma vez que embaralhou os códigos da sua língua e da sintaxe. Aprender significa buscar, ir ao encontro com a travessia do pensamento e reivindicá-lo ao infinito. Aprender significa mais ainda: decifrar os signos da arte literária e de toda especulação de ideias feita pelo jagunço Riobaldo. Cada narrativa, cada conto e cada causo narrado por ele se traduz sob complexos signos e aprendizados diante do mundo, pois todos se reconhecem nessa multiplicidade de signos ou hieróglifos que atravessam a máquina literária do senhor João Guimarães Rosa.

Ora, que tipo de aprendizado podemos extrair do sertão? O professor Riobaldo lança-nos signos a serem decifrados. O desafio está em nós mesmos construir nosso sertão. Nossa travessia. Nosso pensamento. Nossa terceira margem. É esse pensar de 
uma outra forma que mostra o poder do lugar. As astúcias. Somente revelamos nossa força quando pensamos de outra forma, ou seja, de forma criativa em que impera a lei do impensado, ou seja, quando fazemos do pensamento uma verdadeira máquina de guerra e damos a ele velocidades infinitas. Uma coisa é fato: Riobaldo é um professor que pensa: "Mas, hoje, que raciocinei, e penso a eito." (ROSA, 1978, p.21). O professor Riobaldo, como letrado do sertão, faz proliferar uma pedagogia marcada por signos amorosos, aonde a aprendizagem vai sendo construída na medida em que cada signo age como uma violência e vira-nos do avesso. É uma pedagogia que "vai remexer o mundo!" (ROSA, 1978, p. 69), pois rouba a nossa paz e dá o que pensar. A maquinaria roseana está sempre lançando-nos nessa corrente da aprendizagem ao nos fazer deparar com signos nebulosos e obscuros. É esse fundo sombrio que força-nos a pensar. O sertão é o relato de um aprendizado. É nesse pluralismo de signos que nasce a aprendizagem. É essa violência do sertão que nos faz "remexer vivos", em busca da decifração de signos:

O que eu guardo no giro da memória é aquela madrugada dobrada inteira: os cavaleiros no sombrio amontoados, feito bichos e árvores, o refinfim do orvalho, a estrela-d'alva, os grilinhos do campo, o pisar dos cavalos e a canção do Siruiz. Algum significado isso tem? (ROSA, 1978, p. 95)

Riobaldo, em toda sua travessia, somente encontra com signos e lança-nos diante deles. Força-nos a pensar aquilo que ele traz de sua memória involuntária. Afinal, qual o significado desse o daquele signo mundano? Ora, Riobaldo coloca-nos a cada instante nas encruzilhadas do pensamento. Ele mesmo é uma multiplicidade de signos que fala, pensa e age. Riobaldoprofessor, Riobaldo-narrador, Riobaldo-jagunço, Riobaldo-chefe. Na narrativa múltipla, são múltiplos Riobaldos que se desdobram nas margens do pensamento. O sertão, como uma toca, um rizoma, já é uma narrativa habitada pela multiplicidade do pensar. São metamorfoses que se agitam intensamente. No entanto, os signos se desdobram em uma multiplicidade de imagens que se multiplicam, dobram, desdobram e redobram infinitamente. São potências de metamorfoses intensas que agitam a narrativa confusa e estranha de Guimarães Rosa. É nessa pragmática do múltiplo que nasce a aprendizagem. Dessa violência que vem de fora como o diabo na rua, no meio do redemoinho. São essas forças caóticas do demo que nos forçam a pensar. Nesse sentido, a linguagem do avesso é o avesso do pensar. É a possibilidade de decifrar os signos do sertão que estão em toda e nenhuma parte.

O que Riobaldo encontra em sua travessia é o signo nebuloso da "minha neblina", Diadorim e as várias caras do cão. Diadorim e o demo são potências de metamorfoses que entram em intensos devires. O sertão riobaldiano convida-nos a cada instante a construir o nosso próprio sertão. "O senhor estude" (ROSA, 1978, p. 285). Essa é a maior lição que 
podemos extrair das veredas do pensar. Decifrar os signos do sertão implica a aprendizagem. Os signos a serem decifrados na maquinaria roseana, levam-nos para a terceira margem da própria vida. Riobaldo é professor: "Tudo viva! Riobaldo, Tatarana, Professor" (ROSA, 1978, p. 459), pois ele "ia para a escola de Mestre Lucas" (ROSA, 1978, p. 96). Podemos evidenciar o estatuto de professor de Riobaldo Tatarana:

“- Baldo, você carecia mesmo de estudar e tirar carta-de-doutor, porque para cuidar do trivial você jeito não tem. Você não é habilidoso.” Isso que ele me disse me impressionou, que de seguida formei em pergunta, ao Mestre Lucas. Ele me olhou, um tempo - era homem de tão justa regra, e de tão visível correto parecer que não poupava ninguém: às vezes, teve dia de dar em todos os meninos com a palmatória; e mesmo assim nenhum de nós não tinha raiva dele. Assim Mestre Lucas me respondeu: - "E certo. Mas o mais certo de tudo é que um professor de mão-cheia você dava...”'E, desde o começo do segundo ano, ele me determinou de ajudar no corrido da instrução, eu explicava aos meninos menores as letras e a tabuada. (ROSA, 1978, p. 89)

Riobaldo, que gosta de emendar e desemendar as coisas, confunde-nos a todo instante, colocando-nos diante de uma aprendizagem cheia de encruzilhadas. É o sertão a revelação da pura diferença que nos emite signos e nos força a intensas decifrações. Riobaldo, como professor de mão cheia, carecia de tirar carta de doutor. Como um grande sábio do sertão, era apenas um sertanejo que navegava mal das ideias. Mas que desconfiava de muita coisa. Nessa vereda pedagógica, tudo é signo a ser decifrado. É esse encontro com o signo que nos força a pensar. Signos diabólicos, do avesso, do caos, do nada, das veredas e das dobras do pensamento:

O homem nem me olhou, nem disse nenhum agradecimento. Até as solas dos sapatos dele- só vendo- que solas duras grossas, dobradas de enormes, parecendo ferro bronze. (ROSA, 1978, p. 17)

Quando o deserto circunda a linguagem, vemos nascer o mundo "Nonada". É a linguagem do sertão que começa a ser gaguejada. A literatura surge desse nada que é iluminado pela criação poética. Somos arrastados para o deserto. Para o nada da linguagem, para o "fora". O sertão é esse exterior que vaza na terceira margem do pensamento. Nas dobras do pensamento a literatura desdobra e redobra o mundo. Surge nas dobras do pensamento Riobaldo Tatarana. Riobaldo é professor. Mas não é um professor qualquer. É sobretudo um professor que pensa, nos força a pensar e nos faz "remexer vivos" nessas estranhas veredas do pensamento. Faz surgir uma pedagogia estranha, cheia de "ocultos caminhos". Uma pedagogia demoníaca que emerge do redemoinho, das labaredas caóticas do demo. O professor e jagunço Riobaldo vai criando uma pedagogia ao emendar e desemendar uma escritura com cara de cão. Mas que pedagogia é tecida no sertão? Uma pedagogia virada do avesso, que ensina às avessas e nos força a pensar. Pedagogia que corre como um rio, onde tudo vai saindo 
dos escuros, dos ocultos caminhos. Aprendizagem da provisoriedade, pois "é só muito provisório" (ROSA, 1978, p. 15). Do puro devir. Da vida que corre entre fluxos e cortes permanentes. Que aprendizado podemos extrair do sertão? É o aprendizado dos signos, pois o sertão emite signos que nos forçam a decifrar. Assim, já dizia Riobaldo: "Eu queria decifrar as coisas que são importantes. (GSV, p. 79). Somos lançados no intenso fluxo, pois "o sertão está movimentante todo-tempo" (GSV, p. 391). No entanto, nos faz "remexer vivos" uma pedagogia do sertão. "Riobaldo, Tatarana, Professor..." (ROSA, 1978, p. 459, grifo do autor) é mestre que nos faz pensar "na ponta dum pensamento" (ROSA, 1978, p. 69). Enfim, pensar é o que Guimarães Rosa consegue fazer com todos nós. Nos "tirar do eixo" e enfim nos desnortearmos. Contudo, instaura um pensar, um forte pensar e todos nós somos convidados a entrar mata "a fora a dentro" (ROSA, 1978, p. 9). Guimarães Rosa assim, nos colocou para desconfiarmos de nós mesmos, para rirmos de nós mesmos e, certamente nos educar contra nós mesmos ${ }^{1}$, pois " Eu quase que nada sei, mas desconfio de muita coisa" (ROSA, 1978, p. 15). O professor Riobaldo revela sua sabedoria no quase nada saber, ou melhor, no desconfiar de muita coisa. No querer especular ideia e tecer um sertão do "tamanho do mundo". Como um grande mestre, Riobaldo convida-nos a desconfiar das coisas da vida.

No entanto, o ofício do educador é de trocar a confiança pela desconfiança. Em que rio deságua o sertão roseano? Onde Guimarães Rosa buscou inspiração para construir um "sertão do tamanho do mundo", capaz de operar dobras cavernosas e porosas em nosso pensamento? Certamente Guimarães Rosa é um mal dito pois nos força a pensar. "Nonada" o mundo vai se desdobrando infinitamente. Falar do sertão é falar de um mapa de múltiplas dobras. Um sertão cheio de "ocultos caminhos" composto de um múltiplo labirinto, cujo mundo perdeu o seu pivô e vai se desdobrando em uma multiplicidade de imagens. É assim que o sertão roseano vai duplicando o pensamento e arrastando-o ao infinito formando e potencializando uma nova História e uma nova Geografia carregada de um espírito mítico e místico. Rosa criou uma nova geografia do pensamento estético-literário e filosófico arrastando o pensar para o infinito. O que isto significa será nossa próxima travessia.

\section{Sertão: uma geografia do infinito}


O sertão criado por Guimarães Rosa é um instigante desenho de um mapa aberto e conectável em todas as suas dimensões movediças e plásticas uma vez que exige o movimento do pensamento ao infinito. Trata-se de uma nova geografia que se desterritorializa em cada imagem que se edifica em suas veredas. Ora, é bem verdade que a literatura do senhora João Guimarães Rosa é uma pura reivindicação do infinito. É este pensamento que se duplica que está em jogo em suas veredas. Como compreenderam Deleuze e Guattari,

É por isso eu há sempre movimentos infinitos presos uns nos outros, dobrados uns nos outros, na medida em que o retorno de um relança um outro instantaneamente, de tal maneira que o plano de imanência não para de tecer um gigantesco tear ( DELEUZE; GUATTARI, 1992, p. 49)

O que significa dizer que o sertão se desdobra? Quer dizer que as margens roseana são carregadas de múltiplas dobras enigmáticas onde tudo vai saindo desse oco, desse turbilhão cavernoso, agitando massas e arrastando-nos para o redemoinho, fazendo-nos "remexer vivos" e sair do sertão. Mas, já sabemos, que para sair dele, é preciso entrar nele mais a fundo. Com isso, Rosa mostra-nos que é preciso pensar profundamente cada veredazinha. O sertão assim, é um "buraco negro", cavernoso, onde tudo vai saindo do seu contrário, formando uma gastura na cabeça da gente e edificando um forte pensar. Uma violência do pensamento que emerge das labaredas do demo, intensificando uma narrativa demoníaca onde caos e cosmos se juntam em um pé de vento, nos mostrando assim que compreender essa maravilha que é o homem é uma travessia muito complicada como a dobra. Ou melhor, nós mesmos somos essa dobra complexa, pois "o sertão é dentro da gente".

E somos convidados assim a tecer o sertão sendo forte, pois no sertão o que manda é a lei do mais forte. Em que sentido Rosa fala em força? Ora, ser forte no sertão é possuir o poder da palavra, pois como dizia Riobaldo o que é para ser são as palavras. É a força do pensamento e das palavras. Palavras que vão brotando da terra, formando ramas, raizamas, rizomas, dando o que pensar para todos os lados. Encarar o sertão como forma de pensamento é perceber que o sertão é cheio de múltiplas dobras. A dobra do pensamento caminha lado a lado com a dobra da alma, como os ventos que ventilam nos buritizais, pois como dizia Riobaldo: "Mire veja o que a gente é: mal dali a um átimo, eu selando meu cavalo e arrumando meus dobros, e já me muito entristecia (ROSA, 1978, p. 52) (...) Vi que prezava cordial, não me dando por traidor nem falso. Riu redobrado. De repente, desriu. Refez pé para trás. (GSV, p. 70). Assim, nesse tom de alegria, os risos vão se desdobrando, nós arrumando nossos dobros. O narrador 
parece assim dizer que nós somos a dobra. Surge um sertão na explosão do luminoso e ergue-se uma escritura nômade que nos força a pensar e violenta o nosso pensamento. O sertão dentro e fora do pensamento.. Por isso "É e não é. O senhor ache e não ache. Tudo é e não é... (ROSA, 1978, p. 12). Remonta a antiguidade do logos paterno que afirmava a radicalidade do ser, comparando-a com uma esfera, um todo, um redondo. Nessa perspectiva, existe dentro do sertão uma dobra que vai do ser ao não ser, pois o que existe é esse jogo entre o ser e o não ser. Ser e não ser-tão habitam dentro da gente, como a linguagem é morada do homem. E cantava o hino poético ao teorizar a poesia e mostrar que na linguagem poética habita o homem. Hölderlin era o poeta dos poetas. Que nos fez habitar poeticamente essa terra. É nessa relação com a terra que se dá o pensar, pois como dizia Riobaldo:

Melhor se arrepare: pois num chão com igual formato de ramos e folhas, não dá a mandioca mansa, que se come comum, e a mandioca brava, que mata? Agora, o senhor já viu uma estranhez? A mandioca-doce pode de repente virar azangada - motivos não sei. (ROSA, 1978, p. 11)

Rosa vai ao fundo da terra para compreender o enigma que é o homem. Assim como a mandioca doce pode virar azangada, assim é o homem que pode de repente, virar do avesso, ser doce ou azedo, pois como já dizia Heráclito, o mel é ao mesmo tempo doce e amargo. Com isso ele mostra-nos que é preciso pensar mais a fundo. Ir até a raiz, ou diria Deleuze, ao rizoma. É uma escritura embaçada, que nos força constantemente ir até a raiz para compreendermos a nós mesmos. Uma escritura que faz de nós mesmos cães mestres, pois joga uma ideiazinha e saímos latindo. Uma escritura louca que gagueja a língua e vira-nos do avesso. O fora é o diabo que está na rua no meio do redemoinho. É o retrato da força vinda de fora e nos forçando a pensar. Rosa, enfim, dá que pensar nos afeta com sua escritura maldita e faz malditas dobras no pensamento.

Na poética roseana, como evidenciou Kathrin Rosenfield (1967) há um transbordamento de detalhes imaginativos e sensoriais-visuais, acústicos, olfativos e tácteis . Para ela, há um barroquismo que desenrola nas veredas, proliferando uma multiplicidade de imagens, agitando efeitos de massas em um fundo sombrio, intensificando turbilhões, multiplicando as aporias e tudo vai ficando mais nebuloso, aonde o movimento vai tomando conta das veredas, dobrando e (des)dobrando ventos. Assim como a dobra é inseparável do vento, o vento ventila os buritizais. Riobaldo descreve uma lagoa rodeada de buritizais "E, tardinha, quando voltou o vento, era um fino soprado, nas palmas dos buritis, roladas uma por uma" (ROSA, 1978, p. 38). Os 
buritizais ventilando, dobrando sobre si e sobre o mundo numa ventania só. Um pé-devento que se forma se desdobrando no possível posto na encruzilhada quando se evoca a presença do Cujo. O vento, ventilado pelas dobras do leque, desdobra nos buritizais, formando efeitos de massa, intensificando cada vez mais o devir em estado de agitações e turbulências, nos fazendo nos perder no infinito. Foi Wölfflin quem nos mostrou que "O que a arte quer exprimir não é o ser perfeito, mas um devir, um movimento" (WOLFFLIN, 2005, p. 35) Assim, as veredas de Rosa edificam-se no inacabado, na ausência de forma, existindo fora dos cânones, pois sua grande característica é está em toda parte. Sendo assim, nada se fecha. Tudo é transbordamento, onde ao emergir a explosão do luminoso, surge uma neblina, ou melhor dizendo, um signo nebuloso que vai nos impossibilitando a ver o que se encontra na terceira margem a dentro e a fora. Assim, povoa no sertão uma meia luz que vai se deslizando no meio das trevas, formando uma operação infinita, forçando o pensamento a se desdobrar e se intensificar cada vez mais até se perder em um fundo sombrio e cavernoso. Nesse transbordar, somos movidos pela maquinaria barroca que é o sertão, permanecendo assim, um obscuro nas veredas das dobras da alma do escritor, afetando a todos nós e intensificando ainda mais esse obscuro que há no turbilhão de nossa existência, dando assim, velocidades infinitas ao pensamento.

Viver é muito perigoso porque vivemos em um sertão incerto, sem começo e sem fim e que "Sabe o senhor: sertão é onde o pensamento da gente se forma mais forte do que o poder do lugar". (ROSA, 1978, p. 22). É desse "forte pensar" que estamos falando. Pensar forte, com força. Violentar o pensamento. Pensar "na ponta dum pensamento" (ROSA, 1978, p. 69). Pensar. Deixar a linguagem escorrer, acelerando o pensamento. Em outras palavras, o sertão roseano é construído unicamente na linguagem e pela linguagem. Linguagem que vaza, escorre, dobra e desdobra infinitamente. Quem nos força nessa espantosa máquina são os signos que ela revela infinitamente. O signo se estende ao mundo e nos faz perceber que se o sertão está em toda parte e em toda parte os signos estão dobrando e desdobrando sem parar. O sertão mineiro dobra e desdobra atingido o ápice da universalidade. Assim, Riobaldo em suas andanças, faz o mundo se mexer, apelando pela reza por achar que é ela que salva da loucura e que é preciso muita reza para salvar a alma. Seu lado prolixo vai revelando que seu maior gosto é de mudar. Assim, Riobaldo transforma-se no reflexo do próprio homem que muda e corre como um rio. Assim, nessa esteira movente, Bérgson nos mostrou a essência da duração no seu fluir, na criação contínua, no ininterrupto jorro de 
novidades. Para Bérgson, “o movimento não será mais apreendido de fora e, de alguma forma, a partir de mim, mas sim de dentro, nele mesmo, em si." (BÉRGSON, 1984, p. 13).

No entanto, a duração somente existe porque há um fluir intenso nas veredas de Rosa. É uma duração que se alonga sem fim. É o infinito que coloca o pensamento como movente. O Grande sertão: veredas, se desdobra ao infinito, porque é esse infinito do sertão que o coloca movimentante a todo tempo. O sertão roseano transforma-se nesse labirinto fractal dentro de um plano de imanência povoado pela máquina abstrata ilimitada, dentro de um espaço liso que é no deserto, formando uma imagem do pensamento capaz de nos mover para outras bandas do existir. O movimento passa a tomar conta de tudo, pois quando Riobaldo diz que "o melhor de tudo é a água" (ROSA, 1978, p.43), é porque, na concepção deleuzeana, finalmente a própria água dobra. Quando o sertão roseano se desdobra ao infinito, é a alma inventiva de Guimarães Rosa que alcança uma proporção criadora, criando assim uma nova imagem do pensamento, sem começo e sem fim. Um mundo nascido do caos, do oco, se desdobrando em uma multiplicidade de forças que nos forçam a pensar o nosso mundo e a nossa própria condição. Guimarães Rosa nos faz assim construir zonas de vizinhança entre o sertão e o mundo, operando sempre entre fluxos e cortes permanentes e estabelecendo linhas de fuga dentro e fora do sertão. Somente saímos desse sertão, entrando nele mais a fundo e, nessa tensão esquizofrênica, estamos entre o dentro e o fora. Mas como assumir esse jogo entre o dentro e o fora do pensamento? É no livro sobre Foucault que Deleuze vai nos relatar que,

O lado de fora não é um limite fixo, mas uma matéria móvel, animada de movimentos peristálticos de pregas e de dobras que constituem um lado de dentro: nada além do lado de fora, mas exatamente o lado de dentro do lado de fora. (DELEUZE, 2005, p. 104)

Destarte, nesse jogo de fora e de dentro do pensamento o Deleuze-foucaultiano, ou o Foucault deleuzeano em um plano de subjetivação, nos força a pensar nas dobras ou o lado de dentro do pensamento. Para eles, a força do lado de fora não deixa de derrubar os diagramas. No sertão roseano, essa força do fora, é metaforizada em termos diabólicos, pois o diabo é o fora que está dentro do pensamento. É essa força demoníaca que vige dentro do homem, que o arruína e o coloca do avesso que, com toda força vem violentando o nosso pensamento. O sertão é uma forma de pensamento ${ }^{2}$. Ele se constrói, se edifica nesse "pensar de outra forma" deleuzeano, nesse movimento de subjetivação 
topológica. O sertão como força do topos que é capaz de invocar o infinito e mergulhar no caos no lado de dentro e de fora de nossas vidas. Ora, falar que o sertão é o dentro, é, diz o Foucault de Deleuze pensar "um lado de dentro do pensamento mais profundo que todo mundo interior" (FOUCAULT, 2005, p. 15). Assim, o lado de fora do pensamento não é marcado por uma fixidez e sim, é composto de movimentos peristálticos, de pregas e dobras. No entanto, o sertão é esse lado de fora do pensamento. Mas um fora não exterior. O sertão, no entanto, com todas as suas pregas, constitui o lado de dentro da vida e da linguagem que se aloja no homem. Ou, como propôs Heidegger, habita no homem, é a casa do ser. Rosa, como um guarda dessa habitação, fez do sertão a dobra de sua alma. Mas o próprio Heidegger leitor de Parmênides admitiu nos que o pensar vige em virtude da dobra. Por isso, não há, de modo algum e em algum lugar, um vigente fora da dobra. Nesse sentido, o sertão é um aberto mapa cheio de dobras que nos forçam a pensar e nós, somos os descobridores, ou melhor, os decifradores desses signos sombrios que desdobram ao infinito. A dobra sendo nós mesmos, o sertão, estando dentro da gente, somos nós que dobramos e desdobramos o pensamento infinitamente. O Grande sertão: veredas é uma obra que se desdobra. O que isso quer dizer? Quer dizer que ele exprime a dobra, mas ao mesmo tempo a esconde velando e desvelando o ser do ente que nós mesmos somos.

Ora, se o ser e o pensar são a mesma coisa, falar das dobras do sertão é de uma certa forma pensar o ser-tão e suas obscuras dobras do pensamento a dentro e a fora. Assim, no sertão existe uma operação dentro desse lado de fora do pensamento. Onde o dentro não deixa de ser uma dobra do fora, como se um navio fosse uma dobra do mar, utilizando uma expressão usada por Deleuze em Foucault. Mas que força do fora é essa que nos afeta? È a força do diabo que está na rua, no meio do redemoinho e parece que, a qualquer momento, joga todas as sujeiras do mundo em nossa casa e nos vira do avesso. Fazer dessas forças um elemento vital é assumir as dobras ou o lado de dentro do pensamento. O sertão nos tira do norte conduzindo-nos para um forte pensar infinitamente. As dobras da alma dão essa curvatura ao lado de fora do sertão e rizomatiza o lado de dentro, formando um infinito império barroco. $\mathrm{O}$ império barroco de Guimarães Rosa agita-nos em um eterno combate entre o claro e o escuro. Diz Deleuze que "No Barroco, o claro não pára de mergulhar no escuro" (DELEUZE, 1991, p.62). Nesse sentido, o sertão é a revelação máxima de uma linha, de um traço que somente se revela no jogo de um fundo sombrio que movimenta do começo ao fim da obra. Tal fundo é o sertão no seu eterno combate entre o dentro e o fora, entre o é, e o 
não é, ou, diria Heidegger tardio, em seu projeto poemático da verdade, no combate entre mundo e terra. "O senhor ache e não ache. Tudo é e não é...” (ROSA, 1978, p.12). É nessa tensão esquizofrênica que Guimarães Rosa coloca essa nebulosa máquina para funcionar. Uma máquina que provoca em nós grandes efeitos elétricos, anestesiandonos e lançando-nos constantemente no caos. No entanto, a poética roseana violenta o nosso pensamento, movimentando assim uma escrita esquizo capaz de nos lançar para dentro e para fora das margens.

O sertão, sendo o mundo, não deixa de ser uma imensa curva infinita, porque a alma roseana é repleta de infinitas dobras que vão fazendo outras dobras no interior dela mesma. Em outras palavras, no sertão possui outros mundos que se desdobram, como o episódio de Maria Mutema e outros causos que vão se desdobrando nas veredas de Rosa. Surgem mundos possíveis dentro desse cavernoso sertão que vão se alargando e ficando do "tamanho do mundo". A alma como expressão do mundo é revelada na subjetividade roseana, pois por onde passam as mônadas, passa o mundo, tornando-o cada vez mais obscuro, sempre dobrando novos causos, fazendo uma explosão luminosa raiar em cada palavra, como uma caverna dentro da caverna, uma dobra até o encontro com a dobra, assim como o infinito, composto de movimentos curvos. Riobaldo encontra-se diante de curvas e encruzilhadas, constituindo assim, máquinas de máquinas e desenrolando ao infinito.

O sertão roseano é uma imensa casa barroca, constituída de um turbilhão, fazendo surgir novos turbilhões dentro do sertão. Cada causo, cada conto, cada história espantosa que surge no monumento roseano é um turbilhão, formando assim, uma imensa matéria infinitamente esponjosa, porosa ou cavernosa, passando a existir mundos em menores corpos. O que martela no fugidio universo das dobras é a dobra da alma, pois "Lhe mostrar os altos claros das almas: rio despenha de lá, num afã, espuma próspero, gruge; cada cachoeira, só tombos" (ROSA, 1978, p. 23). Guimarães Rosa poetiza de dentro da alma, revela o dentro e o fora das dobras da alma e, com esse desdobrar, deparamos com o mundo rolando, em tombos, como uma cachoeira que corre, desliza, cai turvamente e corre nas curvas do mundo.

Em outras palavras, "O que o pensamento reivindica de direito, o que ele seleciona, é o movimento infinito ou o movimento do infinito. É ele que constitui a imagem do pensamento" (DELEUZE; GUATTARI, 1992, p. 53). O sertão dobra, desdobra e redobra por que ele reivindica o movimento do infinito. Guimarães Rosa como um arquiteto da criação, emenda e desemenda uma narrativa que constitui as 
formas da criação pura que é traduzir, decifrar e interpretar. O que povoa as veredas de Rosa, são esses infinitos movimentos do pensamento. É o que dá a possibilidade para todos nós construirmos um crivo no caos e emergir a cada instante um novo mapa, um novo sertão que dobra e se desdobra a cada instante.

Assim como o claro vai saindo do escuro, o mal vai saindo do bem e o bem vai saindo do mal e sairá sempre uma caverna de dentro da caverna. Dentro desse sertão obscuro desdobra o mundo infinitamente. Mesmo Diadorim que carrega em si a meiguice de uma donzela, dentro dessa meiguice, desdobra um Dia-bólico. Algo une e separa Riobaldo de Diadorim ao mesmo tempo. Ao mesmo tempo no sertão há o dentro e o fora. Um saindo do outro. Caos e cosmos povoam o mundo ao mesmo tempo. Em todos os lados são dobras que se desdobram e aumenta cada vez mais o tecido poético e cavernoso que instala na casa barroca. Wölfflin (2005) nos fez compreender que a casa barroca faz manter sempre viva a comunicação entre o andar de cima e o de baixo e, nesse jogo acima e abaixo, Deus e o diabo transformam-se em apenas uma força que vai saindo de dentro da outra, nos mergulhando a cada instante em novos turbilhões, formando duplos ${ }^{3}$ signos o homem dentro da mulher ou a mulher dentro do homem, a coragem dentro do medo e o mundo é essa eterna guerra de contrários. O sertão é essa máquina que, ao afirmar, imediatamente nega, ou melhor, a negação já possui em si a afirmação que, no fundo sombrio da casa barroca, desdobra-se infinitamente.

Desse modo, Riobaldo, em suas andanças, faz o mundo se mexer, apelando pela reza por achar que é ela que salva da loucura e que é preciso muita reza para salvar a alma. Seu lado prolixo vai revelando que seu maior gosto é de mudar. Assim, Riobaldo transforma-se no reflexo do próprio homem que muda e corre como um rio. Seu espírito aventureiro e religioso faz de si um andarilho contraditório que, ao viver no mundo do avesso, faz desse vasto mundo, um grande sertão cheio de sertõezinhos que são seus causos, sua historietas como ele nos conta sobre Maria Leôncia, Pedro Pindó, o causo de Aleixo, são signos mundanos que vão dando várias direções ao mundo.

Um dos momentos inspirados em que Guimarães Rosa abre o leque das dobras e lequeia o mundo, desdobrando-o poeticamente é “- ah, a papeagem no buritizal, que leque-lequêia" (ROSA, 1978, p. 39). Eis no buritizal a chave de compreensão dessas estranhas veredas de Guimarães Rosa. Levadas pelo vento, aonde "os brejos vão virando rios" (ROSA, 1978, p. 27) e, nesses intensos devires no buritizal, as mutucas 
vem ferroando a gente nos incomodando e, nessas trevas do sertão, nos fazendo mal e dificultando ainda mais a travessia. O "leque-lequêia" é o mundo que vai se abrindo, lequeando franjas de dobras e des/dobrado no meio do buritizal. As múltiplas dobras do leque são ventiladas pelas dobras do vento que abanam no meio dos buritizais.

"De fora e dentro, a literatura é cúmplice daquilo que a ameaça, e essa ameaça é cúmplice da literatura" (BLANCHOT, 1997, p. 32). No entanto, a maquinaria roseananos ameaça porque nos força a pensar o lado de dentro e de fora do pensamento. O Grande sertão: veredas como a dobra de dentro e de fora do pensamento, transformase no espaço da inquietude e da destruição, do caos. É o deserto do lado de fora e do lado de dentro. O sertão é a revelação do fora, da Diferença, que arrasta-nos para o infinito do pensar. Nessa trilha poética, pergunta Michaux "O que é um pensamento? Um fenômeno que trai um espírito - seu quadro- e o que esse quadro desejou" (MICHAUX, 1994, p. 31) O pensamento como traição de si, da escrita, do bando. Certamente Guimarães Rosa traiu o bando ao dobrar, desdobrar e redobrar o pensamento. $\mathrm{O}$ escritor traidor será eternamente malvisto e maldito. Enfim, nessas dobras que povoam o sertão ou o sertão é á própria dobra, o avesso do homem, revela-se um Riobaldo estudioso, sábio, especulador de ideias, que teve Mestre Lucas: "Ia para a escola de Mestre Lucas. A lá, perto da casa de Mestre Lucas, morava um senhor chamado Dodô Meireles... Daí, mestre Lucas e eu tinha de dar uma explicação... (ROSA, 1978, p. 96).

Ora, esse é um dos aspectos extremamente pedagógicos da vida de Riobaldo. Sertão como signo pedagógico, mostra uma travessia de aprendizagem na vida do jagunço que não tinha jeito para cuidar do trivial e sim, merecia, segundo Mestre Lucas, "tirar carta- de- doutor". No entanto, Riobaldo teve um incentivo para a intelectualidade e isso foi percebido pelo seu mestre Lucas que segundo ele, daria um "professor de mão cheia" e Riobaldo era uma espécie de "monitor" de Mestre Lucas e o ajudava no aprendizado dos meninos menores. Assim, o jagunço Tatarana vai tendo uma vida letrada no seio moral, da religião, da palmatória, da regra-de-três, ele raciocinava e aconselhava. Assim, Riobaldo tinha todo um arquétipo de mestre, de especulador, enfim, de pensador que nos faz em vários momentos s confundir as ideias. Isso é o sertão. Essa confusão de ideias, signos e veredas que foram tramadas e narradas pelo Jagunço Riobaldo Tatarana. Afinal, quem é esse Narrador? Veremos.

\section{O narrador Riobaldo}


Ora, para falar da figura de Riobaldo em Grande Sertão: Veredas de João Guimarães Rosa, é preciso primeiro perguntar o que é narrar e como essa narração aparece na obra. De uma forma mais simples, o vocábulo narrar significa: expor minuciosamente, contar, relatar. Abrangendo uma linguagem de cunho teórico, tem-se Benjamin (1983), que fala da arte de narrar, tendo como base a oralidade. Embora para Walter Benjamin experiência tenha caído na cotação e as pessoas não sabem narrar na era da reprodutibilidade técnica, Riobaldo mostra é "matéria vertente" ao narrar o vivido e viver o narrado. Riobaldo faz um relato de suas andanças pelo sertão.

Eu fui contando minha existência. Não escondi nada não. Relatei como tinha acompanhado Zé Bebelo, o foguetório que soltei e o discurso falado, na Pedra-Branca, o combate dado na beira do Gameleiras, os pobres presos passando, com as camisas e as caras sujadas de secos sangues. (ROSA, 1986, p. 135)

Observa-se que os fatos vividos pelo narrador ou por pessoas conhecidas são transmitidos pela literatura oral, uma "contação de causos", bastante comum na região interiorana. Na citação acima, Riobaldo conta para Diadorim que conhecia Zé Bebelo e que para ele tinha trabalhado. É essa transferência de conhecimentos, através das histórias contadas oralmente, que faz de Riobaldo um narrador exemplar. "A experiência que anda de boca em boca é a fonte onde beberam todos os narradores". (BENJAMIN, 1983, p. 58).

Riobaldo acumulou experiências ao longo de sua travessia e presenteia seu interlocutor, com uma magnífica história, tornando-se um narrador por excelência. Segundo Benjamim (1983), narrar vai além de contar histórias, narrar para o autor, é transmitir, é compartilhar, é conhecer e aprender por meio de práticas vivenciadas no cotidiano do ser humano. Tal aprendizado constitui o foco da arte de narrar.

Tudo aponta para a relação que isso mantém com qualquer narrativa verdadeira. Clara ou oculta, ela carrega consigo sua utilidade. Esta pode consistir ora numa lição de moral, ora numa indicação prática, ora num ditado ou norma de vida - em qualquer caso o narrador é um homem que dá conselhos ao ouvinte. (BENJAMIN, 1983, p. 58).

O Narrador Riobaldo colheu informações em suas andanças pelo sertão, transformando-as em experiências, que agora são transmitidas a outros, que por sua vez, devem retransmiti-las dando continuidade à maravilhosa arte de narrar. Percebe-se que mesmo os casos mais simples, trazem explícitos ou implícitos ensinamentos, que cedo ou tarde serão úteis. "Quem narra, narra o que viu, o que viveu, o que testemunhou, mas também o que imaginou, o que sonhou, o que desejou". (LEITE, 2001, p. 6). A autora mostra que a arte de narrar está presente na vida de cada indivíduo, isto é, a arte de 
narrar é a própria essência da vida. Através dela dá-se vazão aos sentimentos e emoções, viaja-se no mundo real e no fantasioso, ensinando e aprendendo. Observa-se que Leite (2001) bebeu da fonte de Benjamin e até o cita em sua obra, buscando confirmar a importância da arte de narrar. O narrador deve trazer internalizadas suas vivências, contando e recontando-as, pois ouvir e contar constitui a teia que dará continuidade a tal tradição. "Narrar histórias é sempre a arte de as continuar contando e esta se perde quando as histórias já não são mais retidas. Perde-se porque já não se tece e fia enquanto elas são escutadas". (BENJAMIN, 1983, p. 62). Vive-se em uma época dominada pela televisão, computador e internet. As pessoas já não conversam mais, até no seio das famílias não há mais diálogo. A grande maioria da população já não se dispõe a contar e ouvir histórias, rompendo assim a transmissão da arte de narrar.

Em Grande Sertão: Veredas, o narrador-personagem Riobaldo é também o protagonista da história. Ele narra segundo seu ponto de vista, porém, não dispõe do poder da onisciência. Ele relata várias narrativas vivenciadas durante sua existência. Começa contando casos de sua infância, sua ida para a casa de seu padrinho Selorico Mendes que, na verdade, era seu pai; depois conta suas aventuras como professor, como jagunço, como chefe e, finalmente, como um rico fazendeiro. Riobaldo reproduz histórias contadas por seus colegas do cangaço, histórias que já eram contadas e recontadas de boca em boca, seguindo a tradição da oralidade, tão bem quista na visão benjaminiana.

\footnotetext{
O narrador entra na categoria dos professores e dos sábios. Ele dá conselho não como o provérbio: para alguns casos - mas como o sábio: para muitos. Pois lhe é dado recorrer a toda uma vida. (Uma vida, aliás, que abarca não só a própria experiência, mas também a dos outros. Àquilo que é mais próprio do narrador acrescenta-se também o que ele aprendeu ouvindo.) Seu talento consiste em saber narrar sua vida, sua dignidade em narrá-la inteira. (BENJAMIN, 1983, p. 74).
}

Segundo Benjamin (1983), o narrador não é um simples contador de histórias, ele é um professor, um sábio, que através de suas narrativas ensina e aconselha. A narração riobaldiana leva o homem a refletir sobre o seu modo-de-ser no mundo. Para isso, Riobaldo lança mão de sua biografia e também nos conta casos inusitados. Sua narrativa foge do senso comum e torna-se extremamente interessante, pois são várias histórias, uma dentro da outra, formando a singular epopéia do protagonista. Ao contar sua vida, Riobaldo expõe os acontecimentos com extrema naturalidade.

E quanto mais natural o modo pelo qual se dá, para o narrador, a renúncia ao matizamento psicológico, tanto maior se torna sua candidatura a um lugar na memória do ouvinte, tão mais plenamente as histórias se conformam a 
experiência pessoal dele, tanto maior é sua satisfação em, mais dia menos dia, voltar afinal a contá-las. (BENJAMIN, 1983, p. 62)

Depreende-se que é responsabilidade do narrador conquistar seus ouvintes. Riobaldo soube agradar seu interlocutor, motivo pelo qual, se prontificou a ouvir sua narrativa até o fim. Para Benjamin (1983), é necessário ter sabedoria ao se contar uma história, pois cabe ao narrador encontrar a melhor maneira, para que sua narrativa seja transmitida e retransmitida de boca em boca, num constante ensino-aprendizagem na travessia do sertão-mundo.

\section{Considerações finais}

Este artigo propôs estabelecer uma complexa dança conceitual entre a Filosofia da Diferença de Deleuze e Guattari e o Grande sertão: veredas do senhor João Guimarães Rosa. Experimentamos alguns signos, devires e fluxos que povoam a Literatura de 1956 desse inovador a linguagem que foi este mineiro de Cordisburgo. Os signos e os aprendizados encontrados na travessia de seu narrador Riobaldo Tatarana se transfiguram e se movimentam fazendo do pensamento uma atividade plástica e móvel como o sertão. Os signos que revelam sua unidade e seu surpreendente pluralismo em que o Narrador depara com o infinito em suas ideias divagadas.

Grande sertão veredas é, poderíamos dizer, uma nova geografia do pensamento. Trata-se de uma escritura nômade na medida em que arrasta o pensamento para fora dos sulcos costumeiros da linguagem e dialoga com as potências do "fora": o demo, o mal, o avesso, a metamorfose, o pacto e o infinito. São essas potências que fazem com que sua escritura seja transgressora, mal dita, rebelde, esquizofrênica e ativadora do pensamento. São essas potências que fazem do sertão uma nova geografia que atua como uma poderosa máquina de guerra no pensamento, desterritorializando- e criando uma nova imagem do pensar: um pensamento sem imagem. O sertão é toda uma narrativa da crueldade, cujos signos operam entre fluxos e cortes permanentes. É a experiência-limite coma linguagem que desliza o pensar em Rosa. Um pensar cujo acontecimento a se dá na experiência desastrosa com a linguagem em Devir,onde tudo se movimenta a todo instante.

Em uma entrevista a Günter Lorenz, em Gênova, em Janeiro de 1965, na ocasião em que ocorreu um Congresso Latino americano, o senhor João Guimarães Rosa declarou duas paixões que são o infinito e a língua. Pelo infinito ele declarou: "Escrevendo, descubro sempre um novo pedaço de infinito. "Vivo no infinito; o 
momento não conta". Com essa declaração Rosa faz nascer uma narrativa cuja linguagem se desdobra ao infinito. É assim que Rosa assume que a vida e a obra não devem se separar. A vida deve fazer justiça à obra e a obra à vida. É assim que o escritor se transforma em arquiteto da alma ao assumir publicamente sua outra paixão pela língua. Essa foi sem dúvida sua grande paixão ao revelar seu devir-escritor: "A língua é o espelho da existência, mas também da alma (...) somente renovando a língua é que se pode renovar o mundo. Devemos conservar o sentido da vida, devolver-lhe esse sentido, vivendo com a língua". Foi assim que Rosa demonstrou sua relação amorosa com a língua pois para ele a linguagem a e vida é uma coisa só. Por isso ele fala da responsabilidade do escritor pois quem não fizer do idioma o espelho da sua personalidade, nãos sobrevive. É esse ato de colocar a língua em variação contínua e gaguejá-la que faz de Rosa um escritor revolucionário, nômade e "filósofo", pois a língua é colocada em Devir. Com essa declaração podemos perceber a paixão de Rosa pela linguagem ao infinito. É sob o signo do infinito que a literatura se faz operando entre fluxos e cortes permanentes da natureza.

O sertão é, de certa forma, uma variação contínua em torno da língua e do pensamento. Como um forte signo, a escritura de Rosa movimenta o pensamento e este se movimenta a si mesmo pela sua força, coerção e arrombamento no pensamento. É o sertão a força viva e ativa do pensar. A geografia do sertão reivindica a metamorfose do pensar, cujo espaço é liso, nômade e deserto. É esse espaço corrosivo, trágico e ameaçador, o espaço literário por excelência.

Em outras palavras, a geografia do pensamento nas veredas de Rosa se edifica em uma forte desterritorialização absoluta cujos signos se multiplicam e arrastam o pensamento ao infinito como uma eterna dobra que duplica a si mesmo e duplica o pensamento reivindicando uma única lei: a do pensamento-vida.

\section{Referências Bibliográficas}

BENJAMIN, Walter; HORKHEIMER, Max; THEODOR, W. Adorno; JURGEN, Habermas. Textos Escolhidos. São Paulo: Abril Cultural, 1983.

BERGSON, Henri. Cartas, conferências e outros escritos; seleção de textos de Franklin Leopoldo e Silva; traduções de Franklin Leopoldo e silva, Nathanael Caxeiro.- 2. ed.São Paulo: Abril Cultural, 1984. (Os pensadores)

Memória e vida; textos escolhidos por Gilles Deleuze; tradução Claudia Berliner; revisão técnica e da tradução Bento Prado Neto. - São Paulo: Martins Fontes, 2006.- (Tópicos) 
BLANCHOT, Maurice. A parte do fogo; tradução de Ana Maria Scherer. - Rio de janeiro: Rocco, 1997.

BOLLE, Willi. O sertão como forma de pensamento. In: Scripta.v.1, 1997, p.259-271.

BRUNO, Giordano. Sobre o infinito, o universo e os mundos; traduções de Helda Barraco, Nestor Deola e Aristides Lobo.- 3. ed.- São Paulo: Abril Cultural, 1983. (Os pensadores)

DELEUZE, Gilles. Foucault; tradução Claudia Sant'Anna Martins; revisão da tradução Renato Ribeiro. - São Paulo: Brasiliense, 2005.

. Conversações. Trad. de Peter Pál Pelbart. São Paulo: Editora 34, 1992.

Proust e os Signos. Trad. de Antonio Carlos Piquet e Roberto Machado.- rio de Janeiro: Forense Universitária, 2003.

Diálogos /Gilles Deleuze, Claire Parnet; Tradução de Eloísa Araújo Ribeiro. -São Paulo: Editora Escuta, 1998.

A dobra: Leibniz e o Barroco; Tradução de Luiz B. L. Orlandi.- Campinas, SP: papirus, 1991.

O Abecedário de Gilles Deleuze, realizado por Pierre-André Boutongproduzido por ÉditionsMontparnasse, Paris. No Brasil, foi divulgado pela TV Escola, Ministério da Educação. Tradução e legendas Raccord.[com modificações]

O que é a filosofia?/ Gilles Deleuze, Félix Guattari; Tradução de Bento Prado Júnior e Alberto Alonso Muñoz.- Rio de Janeiro: Ed. 34, 1992.288p (Coleção TRANS)

FOUCAULT, Michel. As Palavras e as Coisas: uma arqueologia das ciências humanas; tradução Salma Tannus Muchail. - $8^{a}$ ed.- São Paulo: Martins Fontes, 1999. - (Coleção tópicos)

. O Pensamento do Exterior. In: ------.Estética: Literatura e Pintura, Música e Cinema. Organização e seleção de textos: Manoel Barros da Motta. Tradução de Inês Autran Dourado Barbosa. Forense Universitária (Coleção Ditos e Escritos III). Editora

GALVÃO, Walnice Nogueira. As Formas do Falso: Um estudo Sobre a Ambigüidade no Grande Sertão: Veredas. -São Paulo: Editora Perspectiva, 1972.

HEIDEGGER, Martin. Ensaios e Conferências; Tradução de Emmanuel carneiro Leão, Gilvan Fogel, Márcia Sá Cavalcante Schuback.- Petrópolis, RJ: Vozes, 2001.

LEITE, Ligia Chiappini Moraes. O foco narrativo. São Paulo: Ática, 2001.

MALLARMÉ, Stéphane. Poemas; tradução e notas de José Lino Gunewald.- Rio de Janeiro: Nova Fronteira, 1990. 
MEDEIROS, Paulo Tarso Cabral de. Gilles Deleuze e os Fluxos Desejantes em Riobaldo- Política \& trabalho, 14-set/1998-P PGS-UFPB - arquivos.

Travessuras do desejo: signo, rizoma e devir em Grande Sertão: Veredas. Tese de doutorado defendida na UNICAMP em 1997.

MICHAUX, Henri. Um Bárbaro na Ásia, tradução de Denise Moreno Pegorim,- São Paulo: Nova Alexandria, 1994.

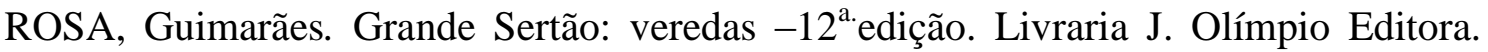
São Paulo, 1978.

ROSENFILED, Kathrin H.A Modernidade Barroca do Grande Sertão: Veredas. In: Letras de Hoje/ Curso de Pós-Graduação em Lingüística e Letras, PUCRS. -n. 1 (out. 1967)-.- Porto Alegre: EDIPUCRS, 1967’.

SÓFOCLES. A trilogia tebatana; tradução do grego, introdução e notas de Mário da Gama Kury.- 11. ed. - RJ: Jorge Zahar Ed., 2004. (A tragédia grega: v. 1)

WÖLFFLIN, Heinrich. Renascença e barroco: estudo sobre a essência do estilo barroco e suaorigem na Itália; [tradução Mary Amazonas Leite de Barros e AntonioSteffen].São Paulo: Perspectiva, 2005. - (Stylus; 7/ dirigida por J. Guinsburg).

[Recebido: 05 out. 2013 / Aceito: 07 dez. 2013] 